\title{
LEIDEN JOURNAL
}

$\mathrm{OF}$

\section{INTERNATIONAL LAW}

\section{Leading Articles}

Judicial Legislation

The Hague Evidence Convention

EC Environmental Regulation
Lord Oliver of Aylmerton E.R. Alley \& D. Prescott J.H. Jans

\section{Student Contributions}

Asylum in the United States

World Communication
M. Meier

H. Hartog 


\section{LEIDEN JOURNAL OF INTERNATIONAL}

\section{Editorial Staff}

Arthur A. Kibbelaar Ricardo, Leading Articles

Gerard J. Tanja, Leading Articles

Rick Lawson, Student Contributions

Melchior Bus, Current Legal Developments (Chairman)

Freek H. van den Engel, Current Legal Developments

Jantine van Bakel, Book Reviews

Natacha Buzaljko (Secretary)

Frans G. von der Dunk (Treasurer)

Joost van Klink (Treasurer)

\section{Board of Recommendation}

Prof. W. Dekker (Chairman)

E.H. van der Beugel

C.D. $\operatorname{van}$ Boeschoten

K.J. Cath

C.H. Goekoop (LL.M.)

Jhr. E. van Lennep

C.M.J.A. Moons

S. Patijn

Prof. A. van Staden

P.A. Wackie Eysten

Dr. G.A. Wagner

Dr. E.P. Wellenstein
Marcel Brus

Astrid J.M. Delissen

Edgar Hennis

Nathalie Horbach

Elisabeth Loudon

Raymond H. van der Meer

Sam Muller

Marielle Paul

Hanna Sevenster

Board of Editors

Prof. P.H. Kooijmans (Chairman)

P.J.G. Kapteyn

Judge Manfred Lachs

M. van Leeuwen Boomkamp

Prof. H.G. Schermers

Prof. PJ. Slat

Prof. H.A. Wassenbergh

\section{Alms}

The Leiden Journal of International Law has been established to promote the understanding of the principles and purposes of international law and to describe current developments. The Joumal aims to attract contributions from students, scholars and practitioners. Particularly attention will be paid to publishing articles written by promising students

Editorial policy

The Journal is published by the Leiden Journal of International Law Foundation. The Editorial Staff is comprised of students and faculty members of Leiden University. The Joumal is not an official publication of Leiden University. The opinions of the authors do not necessarily reflect the opinion of the Journal or any of its members. The Joumal does not accept any responsibility for the views expressed thercin.

Subscriptions

The Leiden Joumal of International Law is published semi-annually in Spring and Autumn.

Subscription prices are per annual volume:

$\begin{array}{lccc} & \text { The Netherlands } & \text { EC } & \text { USA and other } \\ \text { Students } & \text { DIl. } 35 & \text { Dfl. } 45 & \text { Dfl. 50 } \\ \text { Individuals } & \text { Dfl. } 55 & \text { Dfl. } 70 & \text { Dfl. 75 } \\ \text { Institutions } & \text { Dfl. } 60 & \text { Dfl. 75 } & \text { Dfl. 80 } \\ \text { Single issue } & \text { Dfl. } 30 & \text { Dfl. } 40 & \text { Dfl. } 45\end{array}$

All prices include postage and handling. Payments can be made by bank draft personal cheque, national giro, credit card or international money order in Dutch guilders only. Single issues are available from the editorial office. If notice of termination is not received before the expiry of a subscription, it will be renewed automatically. Claims for missing issues will only be considered if made immediately on receipt of the subsequent issue.

\section{Advertising}

Curnent rates and specifications may be obtained by writing to the Secretary at the address below.

Manuscripts, books for review and correspondence should be addressed to the Secretary of the Leiden Journal of International law.
P.O. Box 9520
Tel:(31)-(0)71-277664
2300 RA Leiden
Telex:39427 bunul nl.
The Netherlands
Fax:(31)-(0)71-277600
Bank: ABN 58.09.13.813

Notes for contriloutors and subscription prices will be found on the inside back cover of the Journal. 


\section{LEIDEN JOURNAL}

\section{$\mathrm{OF}$}

\section{INTERNATIONAL LAW}


ISSN 0922-1565

Copyright $\odot 1989$ Leiden Journal of International Law Foundation.

All rights reserved. No part of this Joumal may be reproduced, stored in a retrieval system or transmitted in any form or by any means, electronic, mechanical, photocopying, recording or otherwise without the written permission of the publisher.

This volume may be cited as

2 LIL (1989) 


\section{LEIDEN JOURNAL}

\section{OF}

\section{INTERNATIONAL LAW}

\begin{tabular}{lll}
\hline Volume 2 & May 1989 & Number 1 \\
\hline
\end{tabular}

Editorial

Leading Articles

Lord Oliver of Aylmerton Judicial Legislation 3

E.R. Alley \& D. Prescott Recent Developments in the U.S. under The Hague 19

J.H. Jans Implementation of EC Environmental Regulation 35

Student Contributions

M. Meier Criteria Relating to Eligibility for 'Asylum' and

'Withholding of Deportation' in the United States

H. Hartog Prospects for Future World Communication

Current Legal Developments

$\begin{array}{ll}\text { G.W.Maas Geesteranus Palestine: A State in Embryo } & 79\end{array}$

$M$. van Bremen \& The United States and the Berne International 83

$\begin{array}{lll}\text { D.J.Thibodeau } & \text { Copyright Convention } \\ \text { L.Poffe } & \text { The European Convention on Human Rights: } & 90\end{array}$

M.C.EJ. Bronckers \& The EC Ncw Trade Policy Instrument: A Brief Review 96

M.I.B. Arnold $\quad$ of the Application of Regulation 2641/84

D.C. Buijs The Next Step in European Community Harmonization of

Company Law: Regulation of Public Bids?

Telders Moot Court Competition

The "Right to Insurgency" Case: Sealand v. Lowland

Book Reviews
A. Roberts \&
B. Kingsbury (eds.)
Bin Cheng \&
E.D. Brown (eds.)
A. Bloed
Th. Meron

R.R. Churchill \&

A.V.Lowc
United Nations, Divided World (M. Fitzmaurice)

Contemporary Problems in International Law (M. Brus)

The External Relations of the Council for Mutual Economic

Assistance (J. Herman)

Human Rights in Internal Strife: Their Intcrnational

132

Protcction (R. Lawson)

The Law of the Sca (GJ. Tanja) 